\title{
Labyrinthe
}

31 | 2008 (3)

Revues modes d'emploi

\section{Le fait juif au regard de l'épistémologie}

Sur deux livres de Jean-Michel Salanskis : Extermination, loi, Israël.

Ethanalyse du fait juif et Talmud, science et philosophie

Frédéric Keck

\section{OpenEdition}

Journals

Édition électronique

URL : http://journals.openedition.org/labyrinthe/3878

DOI : $10.4000 /$ labyrinthe.3878

ISSN : 1950-6031

Éditeur

Hermann

Édition imprimée

Date de publication : 15 octobre 2008

ISBN : 978-2-9526131-8-7

Référence électronique

Frédéric Keck, « Le fait juif au regard de l'épistémologie », Labyrinthe [En ligne], 31 | 2008 (3), mis en ligne le 08 novembre 2008, consulté le 24 septembre 2020. URL : http://journals.openedition.org/ labyrinthe/3878; DOI : https://doi.org/10.4000/labyrinthe.3878

Ce document a été généré automatiquement le 24 septembre 2020.

Propriété intellectuelle 


\section{Le fait juif au regard de l'épistémologie}

Sur deux livres de Jean-Michel Salanskis : Extermination, loi, Israël.

Ethanalyse du fait juif et Talmud, science et philosophie

Frédéric Keck 